\title{
Symptomatic geographic tongue in a child
}

\author{
*Md. Ashif Iqbal' ${ }^{1}$,Jesmin Mohol $^{2}$, K M Asrafuzzaman Momin ${ }^{3}$ \\ Sri Lanka Journal of Child Health, 2020; 49(4): 414-415 \\ DOI: http://dx.doi.org/10.4038/sljch.v49i4.9283 \\ (Key words: Tongue lesion, geographical tongue, benign migratory glossitis, zinc supplement)
}

\section{Introduction}

Benign migratory glossitis (geographic tongue) is commonly found on routine clinical examination as an asymptomatic, ulcer-like region on the dorsum of the tongue where the filiform papillae are denuded $^{1}$. It can recur at different tongue locations and in most cases, will resolve completely ${ }^{1}$. However, rarely, geographic tongue in children can be symptomatic, presenting with oral pain which affects daily activity, eating, and sleeping ${ }^{1}$.

\section{Case report}

A girl aged 2 years and 9 months was brought to the department of periodontology and oral pathology, the chief complaints being oral pain and burning ulceration that created difficulty in eating and drinking. Extra-oral examination revealed normal facial morphology. Examination of the mouth showed that filiform papillae were absent but there was an irregular map-like patch with a red and white lesion with white circular borders on the entire dorsal lingual surface. (Figure-1)

It was diagnosed as a geographic tongue. Patient's parents were advised and reassured regarding the tongue lesion. Parents were advised to give plenty of fluids and to maintain proper oral hygiene especially of the tongue and to give vitamin Bcomplex + Zinc syrup supplement for geographic tongue. Patient was recalled for regular follow-up. After one month follow-up visit the lesion showed drastic healing (Figure-2)

${ }_{1}^{1}$ Associate Professor \& Head, Dept. of Oral Pathology \& Periodontology, ${ }^{2}$ Senior Lecturer, ${ }^{3}$ Internee Doctor, Update Dental College \& Hospital, Harirampur, Dhaka, Bangladesh

\section{*Correspondence: drasif100@gmail.com iD orcid.org/ 0000-0002-9490-7927}

(Received on 20 February 2019: Accepted after revision on 26 April 2019)

The authors declare that there are no conflicts of interest

Personal funding was used for the project.

Open Access Article published under the Creative

Commons Attribution CC-BY (c) (i)

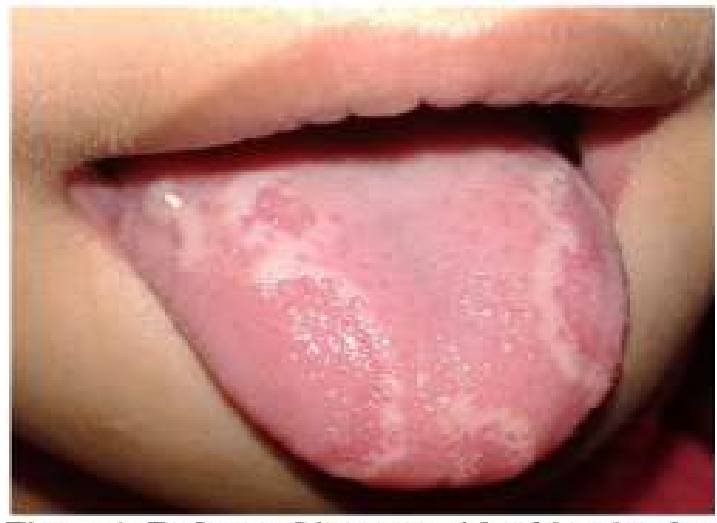

Figure 1: Red atrophic areas with white circular borders on lateral and dorsal lingual surfaces

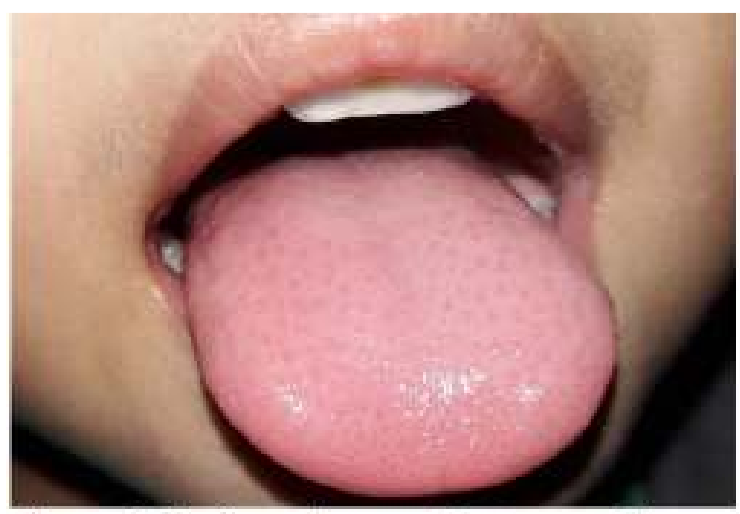

Figure-2: Healing of geographic tongue after one month follow-up visit

\section{Discussion}

Geographic tongue was first reported by Rayer ${ }^{2}$. As the lesion appears map-like, it was called "geographic" and as it can change its pattern over time, it was called "migratory". The exact aetiology of geographic tongue is unknown ${ }^{1,3}$. It has a low prevalence in children compared to adults ${ }^{4}$. The low prevalence in children is probably due to it being ignored by parents due to its asymptomatic nature ${ }^{3}$. Differential diagnosis of geographic tongue includes candidiasis, leucoplakia, psoriasis, neutropenia, local trauma and drug reaction ${ }^{3}$. Asymptomatic cases require only reassurance about the benign nature of the lesion, but symptomatic cases need therapy ${ }^{3}$. Use of antihistamines and local anaesthetic rinse have been successful in symptomatic cases ${ }^{5}$. If significant pain persists, topical and systemic antihistamines ${ }^{6}$, Vitamin A acid therapy and 
systemic acitretin $^{6}$, systemic cyclosporine ${ }^{7}$, topical corticosteroids $^{8}$ and topical tacrolimus ointment ${ }^{9}$ may be useful.

\section{References}

1. Sigal MJ, Mock D. Symptomatic benign migratory glossitis: report of two cases and literature review. Pediatric Dentistry 1992; 14(6): 392-6.

PMid: 1303549

2. Prinz H. Wandering rash of tongue (geographic tongue). Dent Cosmos 1927; 69: $272-5$.

3. Mehta V. Benign migratory glossitis: Report of a rare case with review of literature. Journal of Dental Health, Oral Disorders and Therapy 2017; 6(4) Available from:

https://medcraveonline.com/JDHODT/JD HODT-06-00210

4. Shulman JD. Prevalence of oral mucosal lesions in children and youths in the USA. International Journal of Pediatric Dentistry 2005; 15(2): 89-97 https://doi.org/10.1111/j.1365263X.2005. 00632.x

PMid: 15790365

5. Neville BW, Damm DD, Allen CM, Bouquot JE. Dermatologic diseases In:
Oral and maxillofacial Pathology. (3rd ed.), St Louis, Saunders Elsevier, Missouri, USA, 2002 pp. 779-81.

6. Assimakopulos D, Patrikakos G, Fotika C, et al. Benign migratory glossitis or geographic tongue: An enigmatic oral lesion. American Journal of Medicine 2002; 113(9): 751-5. https://doi.org/10.1016/S00029343(02)01 379-7

7. Abe M, Sogabe Y, Syuto T, Ishibuchi H, Yokoyama Y, et al. Successful treatment with cyclosporin administration for persistent benign migratory glossitis. Journal of Dermatology 2007; 34(5): 3403.

https://doi.org/10.1111/j.13468138.2007.0 0284.x

PMid: 17408445

8. Cameron AC, Widmer RP. Pediatric oral medicine and pathology In: Handbook of Pediatric Dentistry. (3rd ed), Mosby Elsevier, Missouri, USA, 2012 pp. 192-3.

9. Purani JM, Purani HJ (2014) Treatment of geographic tongue with topical tacrolimus. BMJ Case Reports Rep 2014: bcr-2013201268

https://doi.org/10.1136/bcr-2013-201268 